DOI https://doi.org/10.18551/rjoas.2020-10.23

\title{
COMPARATIVE ANALYSIS OF THE INFLUENCE OF SERVICE QUALITY AND PROMOTION ON ONLINE TRANSPORTATION SERVICES CUSTOMER SATISFACTION IN PALEMBANGS, INDONESIA
}

\author{
Maulana Ahmad \\ Faculty of Economics, University of Sriwijaya, Indonesia \\ Novalia Nurkardina, Raneo Agung Putra, Wita Farla W.K. \\ Faculty of Economics, University IBA, Indonesia \\ *E-mail: maulanaahmad075@gmail.com
}

\begin{abstract}
This study aims to analyze and test the customer satisfaction model of online transportation services in Palembang. The variables observed in the customer satisfaction model are service quality and promotion. This study uses primary data obtained by distributing questionnaires online using google doc. The respondents in this research are people who live in Palembang city at least 17 years old and people who have used go-ride and grab-ride online transportation services at least 10 times in the last 3 months. The sampling technique included in this study used accidental sampling. Data analysis with multiple regression methods (ordinary least squares) was carried out by researchers using the SPSS program to determine the effect of service quality and promotion on customer satisfaction. The result reveals that the quality of go-ride and grab-ride services has a significant effect on Customer Satisfaction of Online Transportation Services in Palembang City and the Go-ride and GrabRide Promotion variables have a significant effect on Customer Satisfaction of Online Transportation Services in Palembang City.
\end{abstract}

\section{KEY WORDS}

Service quality, promotion, customer satisfaction.

Currently the service business is increasingly diverse in order to meet the needs of society. According to Setiyanto (2016), means of transportation and communication cannot be separated from human life because these two things are often used to facilitate all human work. The use of technology is not only in the field of communication, but technology is used in the fields of education, economy, agriculture, security and transportation.

Transportation services are currently considered important, especially with the increasing population of an area. Urban areas, for example, a larger population and high mobility of people and also congestion problems that make the reason why people are more selective in choosing a means of transportation that is able to move to their destination. faster, affordable prices, good service quality, and safer.

One type of transportation service that is popular and often found in urban areas is a motorcycle taxi. Ojeks are motorbikes that function as public vehicles that carry people or goods that charge an agreed fee. This growing mode of transportation is also influenced by the development of the number of motorized vehicles which increases from year to year compared to other vehicles.

The number of motorized vehicles in Indonesia in 2015 reached 121.39 million units. Data from the Central Bureau of Statistics (BPS) shows that most of these numbers are motorbikes with a total of 98.9 million units $(81.47 \%)$ of the total vehicles. Passenger cars were 13.5 million units $(11.12 \%)$, freight cars 6.6 million units $(5.44 \%)$, and buses 2.4 million units (1.98\%) (www.databoks.katadata.co.id, accessed on 11 November 2019).

Along with the development of technology there are applications that introduce ojek ordering services using technology and using service standards where ojegs are ordered and paid for in an online system. One of the online motorcycle taxi service providers is PT Gojek 
Indonesia or called Go-ride and PT. Grab or known as Grab-ride. Go-Jek was founded in 2011 by the son of Indonesia who graduated from Harvard University, Nadiem Makarim. In January 2015, the company launched a location-based search based Gojek mobile application for smartphones based on android and iOS (apple). Go-jek has operations in 50 cities from 30 provinces in Indonesia.

Grab is one of the $\mathrm{O} 2 \mathrm{O}$ platforms founded in 2012 by Anthony Tan and Tan Hooi Ling, headquartered in Singapore and most frequently used in Southeast Asia. They provide daily necessities for customers including travel, food delivery, delivery of goods - and payment using digital wallets. Grab currently provides services in Singapore, Indonesia, Philippines, Malaysia, Thailand, Vietnam, Myanmar and Cambodia. Grab now holds the status of the first "decacorn" startup in Southeast Asia. As for Go-Jek and Grab competitors, namely Uber from Europe, and other local online motorcycle taxis such as Oke-Jack, Indo-Ojek, Tekno, AJO.

In the midst of this intense competition, transportation service companies are competing to gain as much market share as possible so that it will become a service that is expected to become a market leader or market leader among products. According to data disclosed by Robin Muliady, who is the Media Director of Go-Jek's Consumer Choices, he has become the market leader in application-based transportation with a fleet of 500,000 GoJek drivers spread throughout Indonesia. One of the main keys to the company's success is customer satisfaction because currently customers are increasingly selective in choosing one of the alternative options as desired.

Based on the observations made by the author at the Sriwijaya University in Palembang, it is known that 7 out of 10 people who use online motorcycle taxi transportation services choose Go-Ride and Grab-ride as their online transportation tools, for various reasons, including safer, more comfortable, cheap and fast.

According to Kotler \& Keller (2016) satisfaction is the feeling of being happy or disappointed by someone that arises because of comparing the perceived performance of the product (or results) against their expectations. The theory that explains how customer satisfaction or dissatisfaction is formed is "The Expectancy Disconfirmation Model" which states that satisfaction and dissatisfaction is the impact of the comparison between expectations and what the customer actually gets from the product purchased. Satisfaction and dissatisfaction of Go-Ride and Grab-ride customers can be conveyed by customers by providing ratings or values to Go-Ride and Grab-ride services that have provided services to customers. The rating for Go-Ride and Grab-ride services consists of five stars chosen by the customer. The more stars that are given means the service provided is more satisfying.

Go-Jek customer satisfaction can also be seen on the playstore page for Androidbased mobile phones. Customers can also provide ratings and reviews of Go-Jek services. Observations made in April 2019 showed a rating like the following picture:

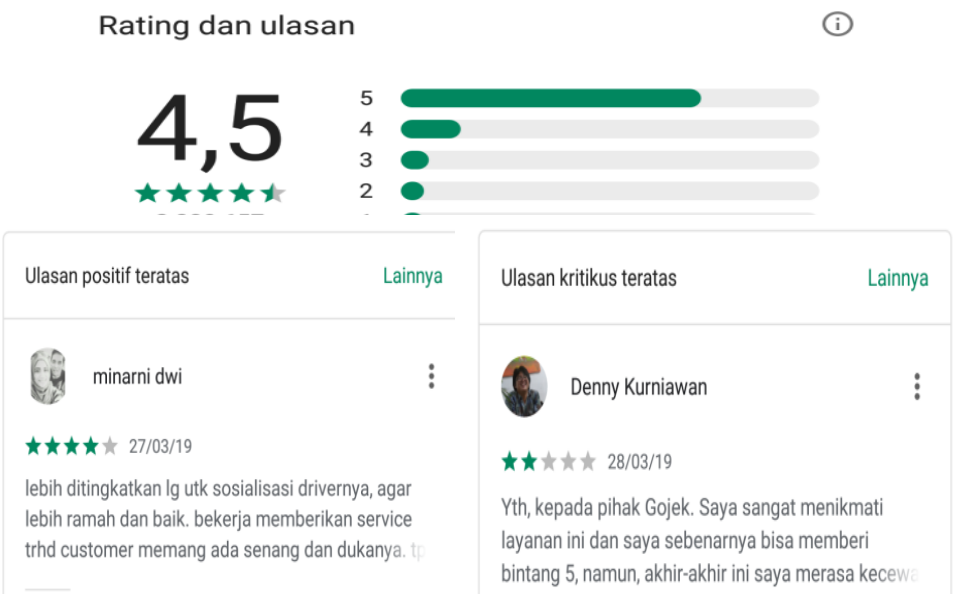

Figure 1 - Gojek Ratings and Reviews on the Android Playstore source: Android playstore (accessed April 5, 2019) 
From the reviews in Figure 1, Go-Jek's customer rating is at 4.5 out of 5 . This proves that the level of satisfaction is high. In Figure 1 there are also two customer reviews regarding Go-Jek's services. Grab customer satisfaction can also be seen on the playstore page for Android-based mobile phones. Customers can also provide ratings and reviews of the Grab service. Observations made in December 2019 showed a rating like the following picture.
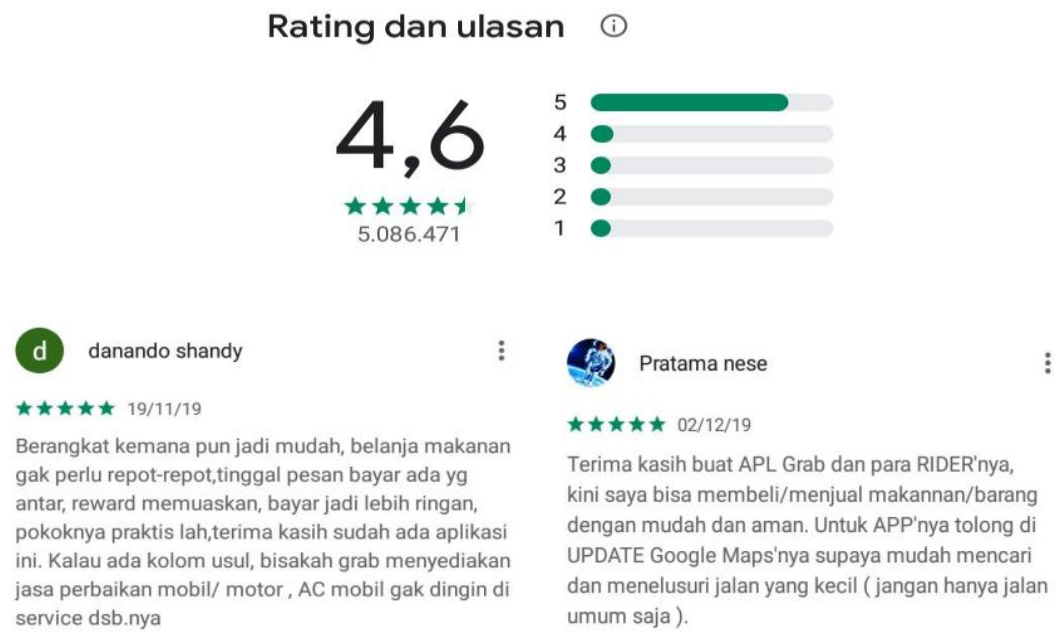

Figure 2 - Rating and Reviews of Grab on the Android Playstore source: Android playstore (accessed April 5, 2019)

From the reviews in Figure 2, the rating for Grab customer ratings is 4.6 from 5 . This proves that the level of satisfaction is high. Figure 2 also explains two customer reviews regarding Grab services.

The Indonesian Consumers Foundation (YLKI) conducted a survey of users of online transportation services (ride hailing) on April 5-16 2018 involving 4,668 respondents spread across 7 major cities such as Jakarta, Bandung, Surabaya, Medan, Palembang, Makassar, and Semarang. Respondents consisted of $55 \%$ male and $45 \%$ female. The survey results stated that the level of customer satisfaction was $59 \%$ of respondents who were satisfied while $41 \%$ had experienced disappointment with online transportation. The following data describes customer disappointments or complaints against online motorcycle taxis according to YLKI.

Table 1 - Complaints from YLKI Online Ojek Survey Customers

\begin{tabular}{lll}
\hline No & Types of complaints from online motorcycle taxi customers & Total \\
\hline \hline 1 & Driver asked to cancel & $22,30 \%$ \\
2 & It's hard to get a driver & $21,19 \%$ \\
3 & Drivers cancel unilaterally & $18,72 \%$ \\
4 & Application map error & $16,00 \%$ \\
5 & License plates are not the same as the vehicle being carried & $12.00 \%$ \\
6 & The driver didn't come & $6,30 \%$ \\
7 & The condition of the vehicle is not good & $6,00 \%$ \\
8 & Drivers are dishonest with consumers & $5,00 \%$ \\
9 & Drivers embark on a journey before meeting consumers & $4,97 \%$ \\
10 & Inconsiderate driver & $4,70 \%$ \\
11 & The vehicle smells of cigarette smoke & $4,60 \%$ \\
12 & Driver nagging & $2,80 \%$ \\
13 & Driver smokes while driving & $0,72 \%$ \\
\hline
\end{tabular}

Source: www.ylki.co.id (accessed on March 25, 2019).

One of the factors that influence customer satisfaction is service quality. According to Parasuraman (2014) service quality includes several aspects which include: the ability to 
provide immediate and satisfying services (reliability), the desire of employees to help customers and provide responsive service (responsiveness), ability, politeness, and the trustworthiness of employees (assurance), ease of establishing good communication relationships and sincere attention to customers (empathy), and evaluation of physical facilities (tangibles).

The services offered by Go-Jek are very diverse, such as go-food, go-send, go-life, gotix, go-car, go-glam, go-bluebird, go-pulse, go-massage, go-laundry, go -fix, go-clean, goauto, go-glam, go-bills, go-shop, go-mart, go-box, go-daily, go-med, go-deals, go-points, and go-nearby. Meanwhile, Grab services such as Grab-ride, Grab-car, Grab-Food, GrabExpress, Grab-Taxi, and services such as credit purchases or electricity tokens, bills, hotel reservations, and cinema ticket reservations. This study discusses the quality of service on Go-Ride and Grab-ride services because by utilizing these services, customers can experience services from ordering to their destination.

PT Gojek Indonesia and PT Grab as a pioneer company that initiated online motorcycle taxi transportation services were able to grab market share and the Go-Jek and Grab brands have been ingrained in the minds of the people. With the Go-Jek and Grab brands in the minds of people, they will remember the green ojek, often seen on the streets, and often in pronunciation, people often mention Go-Jek even though consumers use other online transportation services.

Promotion is a marketing program that can increase the sales success of the product. This is because consumers need information about the product before making the purchase process. In essence, promotion is a form of marketing communication, namely marketing activities that seek to spread information, influence or persuade, and / or remind the target market of the company and its products to be willing to accept, buy, and be loyal to the products offered by the company concerned (Tjiptono, 2014). So promotion can be the basis of information that consumers have to make purchases.

The promotion strategy requires one very important aspect, namely a communication tool as a means of channeling the message that the company wants to convey to consumers so that messages can be easier to understand and consumers can know with certainty about the information about the product. In the world of marketing, the term "media" means a means of communication such as newspapers, magazines, radio, television, billboards, pamphlets, and the internet. Advertisers use the media to convey commercial messages to their target market, and these media depend on different levels of advertising spending to cover these operational expenses (Rajagopal, 2012).

The rapid development of online transportation services, especially Go-Ride and Grabride, is one of the reasons for the need for an in-depth study, especially from the customer's perspective. How does a customer respond to online transportation called Go-Jek and Grab, how does a customer consider the quality of service when using this transportation service because it has become a pioneer or top of mind in terms of online motorcycle taxi transportation in Indonesia.

Based on this description, it is felt to be interesting to conduct research on "Comparative Analysis of Service Quality and Promotion on Online Transportation Services Customer Satisfaction in Palembang, Indonesia".

\section{THEORETICAL REVIEW}

Service quality. According to Parasuraman (2014), the concept of expected and perceived service quality is determined by service quality. Quality of service consists of responsiveness, assurance, physical evidence, empathy and reliability. In addition, the service expected is strongly influenced by various perceptions of word of mouth communication, personal needs, past experiences and external communication, this perception is what influences the service expected (Ep = Expectation) and perceived service $(\mathrm{Pp}=$ Perception) the concept of service quality. More details can be shown in the image below: 


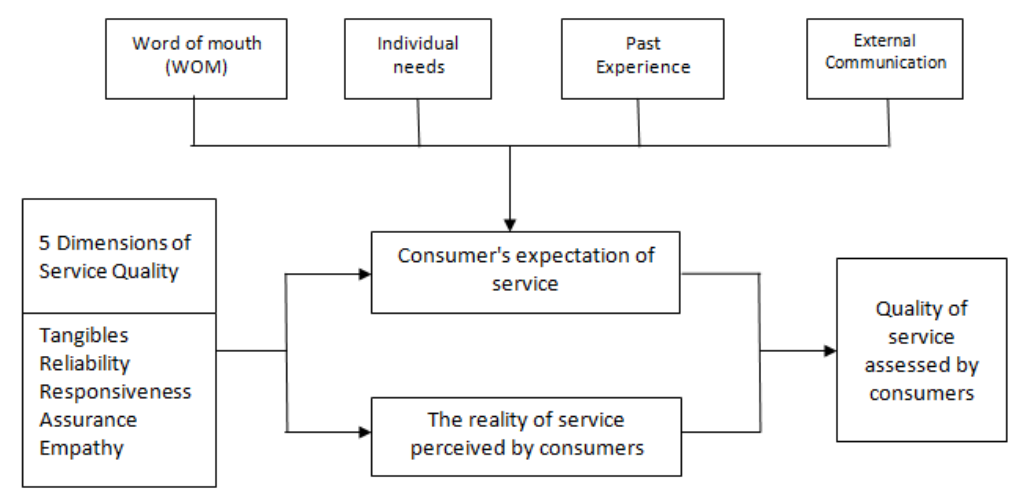

Figure 3 - Customer Assessment of Service Quality Source: Parasuraman (2014)

Mowen and minor (2012) define service quality as a comprehensive customer evaluation of the goodness of goods and services. The main issue in assessing product performance is what dimension consumers use to evaluate it.

Parasuraman (2014) states that the concept of service quality is a complex definition of quality, about satisfying or unsatisfactory. The concept of service quality is said to be of quality if the expected service is smaller than the perceived service (quality). It is said that the concept of service quality meets expectations, if the expected service is the same as what is felt (satisfying). Based on the above understanding, there are three levels of service quality concept, namely:

- Quality (quality surprise), if the fact that the service received exceeds the service expected by the customer;

- Satisfactory (satisfactory quality), when the fact that the service received is the same as the service expected by the customer;

- Unacceptable quality, if in fact the service received is lower than what the customer expected.

The description above becomes an assessment in determining various types of service quality measurement models. Kotler \& Keller (2016) defines service (service) is all actions or performance offered by one party to another party which is essentially intangible (intangible) and does not result in any ownership.

First, services or services differ according to whether they are human-based or equipment-based. The accuracy of the service marketing strategy of a company is determined by the perceived service quality offered and measured by service performance / perceived service and consumer expectation. The success or ability of a company's service quality is assessed in displaying the elements of service quality.

Parasuraman (2014) suggests five main dimensions of service quality, as follows:

- Reliability, related to the company's ability to provide accurate service from the first time without making any mistakes and delivering its services according to the agreed time;

- Responsiveness, with regard to the willingness and ability of employees to help customers and respond to their requests, and to reflect when services will be provided and then provide services quickly;

- Assurance, namely the behavior of employees is able to foster customer trust in the company and the company can create a sense of security for its customers. Assurance also means that employees are always up to date with the knowledge and skills needed to handle any customer question or problem;

- Empathy (empathy), which means that the company understands the problems of its customers and acts in the interests of customers, as well as giving personal attention to customers and having comfortable operating hours;

- Physical evidence (tangibles), relating to the attractiveness of physical facilities, equipment and materials used by the company, as well as the appearance of employees. 
The success or ability of a company's service quality is assessed in displaying the elements of service quality. The dimensions of service quality that customers perceive are shown in the following figure:

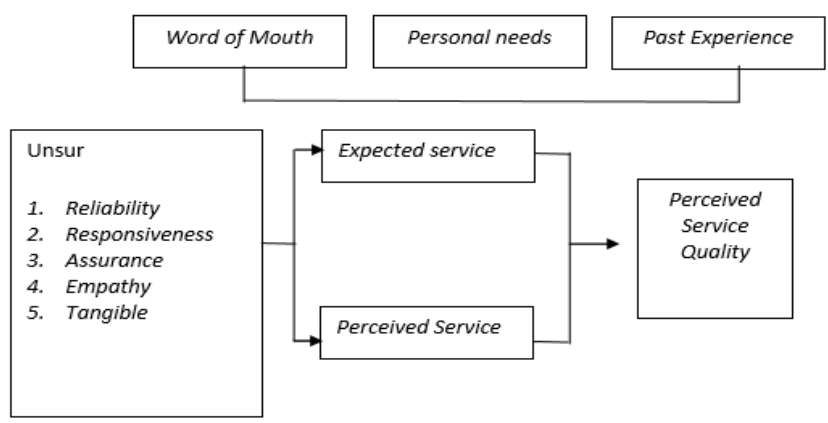

Figure 4 - Dimensions of Service Quality Perceived by Customers Source: Tjiptono (2014)

Promotion. Promotion is one of the important variables in the marketing aspect, according to Kotler and Keller (2016) promotion is one of the variables of the marketing mix that is important for companies to market their products by advertising or other activities that aim to encourage demand for products.

The definition of promotion explains that promotional activities are used to provide information to consumers about products or services. The promotion has several types of media or promotional channels. Solomon and Stuart (2003) argue "advertising is a form of non-personal communication paid for by sponsors who use the mass media to tell or inform something to consumers". There are several types of advertising promotions that are commonly used such as newspapers, direct mail television, radio, magazines, billboards or billboards, brochures, telephones, and the internet.

Kotler \& Keller (2016) suggest that promotion has component components that are summarized in the promotional mix which consists of:

1. Advertising. Advertising is all forms of non-personal presentation and promotion of ideas, goods or services paid for by certain sponsors. Advertising is one of the four main tools a company uses to facilitate persuasive communication with buyers and the public. This persuasive communication is intended to create a satisfying exchange;

2. Sales promotion. Sales promotion is a promotional activity other than advertising, personal selling, and publicity. Activities included in the sales promotion category include: demonstrations, exhibition shows, demonstrations and so on. Usually this activity is carried out in conjunction with other promotional activities and the cost is relatively cheaper than advertising and personal selling. In addition, sales promotions are also more flexible because they can be done at any time;

3. Personal selling. In personal selling, there is direct interaction, face to face meeting between the buyer and the seller. Communication made by both parties is individual and two-way, so that the seller can directly get feedback about the wishes of the buyer. Their delivery of news or conversations is very flexible because it can adapt to the current situation;

4. Publicity. Publication is part of a broader function, namely public relations and maintaining a beneficial relationship between the organization and the community as well as potential buyers. The definition of publicity itself is a number of information about a person, goods or organization that is disseminated to the public through the media without being charged or supervised by sponsors;

5. Direct Marketing. Direct Marketing is an interactive marketing system that uses one or more advertising media for measurable responses and / or transactions anywhere.

Customer satisfaction. The word satisfaction (satisfaction) comes from the Latin "satis" (meaning good enough, adequate) and "facio" (doing or making). Satisfaction can be defined 
as "fulfillment efforts". Satisfaction is the feeling of being happy or disappointed by someone that arises because of comparing the perceived performance of a product or service against their expectations (Kotler and Amstrong, 2012).

According to Tjiptono (2014) customer satisfaction is an after-purchase evaluation in which the chosen alternatives at least give results (outcomes) equal to or exceed customer expectations, while dissatisfaction arises if the results obtained do not meet customer expectations.

Yuliarmi and Riyasa (2014) state that customer satisfaction is a function of the difference between the performance produced and the expectations that performance has been compared.

Kotler and Keller (2016) explain that consumer satisfaction is a feeling of pleasure or disappointment that arises from comparing the product's perceived performance (or results) against their expectations.

Mardikawati and Farida (2013) argue that indicators of customer satisfaction in transportation services are:

1. The suitability of the service as expected, in this case it relates to the perception of the customer whether the quality of the service received is in accordance with what the service provider has promised to the customer's expectations.

2. The suitability of the service with the tariff paid, in this case, is related to the customer's perception of how they feel whether the service they receive is in accordance with the fee or rate they have paid to consume the service.

3. Customer satisfaction with the services offered, in this case related to the perception of whether or not the customer is satisfied with the services offered compared to other service providers.

Understanding the needs and wants of consumers in this regard is an important thing that affects customers. Consumers who use services, in this case, customers who have been satisfied are very valuable assets because if they are satisfied, the service user will continue to use the service according to his choice, but if not satisfied the user will tell twice as badly about the experience he has experienced.

Basically, customer satisfaction and dissatisfaction with a product or service will affect the subsequent behavior patterns. If the service or service user is satisfied, then he will show the big possibility to return to using the same service or service, namely Go-Jek. Satisfied service program users are also likely to provide good references to services or services.

According to Tjiptono (2014) several methods companies use to monitor customer satisfaction, including:

1. The complaint and suggestion system provides an opportunity for customers to submit suggestions, complaints and customer opinions regarding products or services. This method is passive, so it is rather difficult to get a complete picture of customer satisfaction or dissatisfaction. Not all dissatisfied customers will complain, customers may switch to other service providers and no longer use the service provider;

2. Customer satisfaction survey. Customer satisfaction surveys can be conducted by means of a questionnaire, either by post, telephone or by personal interview. Through a survey the company will get responses and feedback directly from customers as well as provide a positive sign that the company is paying attention to its customers. Measuring customer satisfaction through this method can be done in various ways, including:

- Directly Reported Satisfaction: Measurement is carried out directly to consumers through statements such as an expression of how satisfied you are with the company's service with the following scale: very dissatisfied, dissatisfied, dissatisfied, satisfied, very satisfied;

- Derived dissatisfaction: the statement put forward concerns two main things, namely the amount of consumer expectations for certain attributes, and the amount of performance they feel; 
- Problem analysis: consumers who become respondents are asked to reveal two main points. First, the problems they face are related to the company's offerings. Second, suggestions for improvement;

- Importance-performance analysis: in this technique, respondents are asked to rank the various elements / attributes.

Mar'ati (2016) The Effect of Service Quality and Price on Customer Satisfaction of Online Ojek Transportation Services (Study on Go-Jek Consumers in Surabaya). The results showed that service quality and price had a significant effect on customer satisfaction both simultaneously and partially.

Aghnia Anumillah (2016) The Effect of Service Quality on Customer Satisfaction (Study on Go-Jek Consumers in DKI Jakarta). The results of this study indicate that the independent variables of service quality have an effect on customer satisfaction.

Gilang Fhitryan Widsya Pratama (2017) The Influence of Service Quality on Customer Satisfaction of Online-Based Taxi Services (Grab-Car) for Students at the University of North Sumatra. The results showed that service quality had a significant effect simultaneously and partially on customer satisfaction.

Sheng \& Liu (2010) An empirical study on the effect of e-service quality on online customer satisfaction and loyalty. The results show that efficiency and fulfillment have a positive effect on customer satisfaction, and fulfillment and privacy have a positive effect on customer loyalty. However, besides that, customer loyalty is positively influenced by customer satisfaction.

Rehman (2012) Customer satisfaction and service quality in Islamic banking $A$ comparative study in Pakistan, United Arab Emirates and United Kingdom. The results reveal that Pakistani and British Islamic banking customers consider assurance, reliability and empathy as significant factors for customer satisfaction, while customers of the Arab Emirates Unit consider assurance and tangibility as significant dimensions of satisfaction.

Joon \& Sik (2013) The impact of outcome quality, interaction quality, and peer-to-peer quality on customer satisfaction with a hospital service. The results showed that the quality of results, quality of interaction, and quality of peer-to-peer perceptions significantly affected customer satisfaction, which, in turn, greatly affected customer loyalty.

\section{METHODS OF RESEARCH}

This research was conducted in Palembang City with the object of research being people who live in Palembang city at least 17 years old and people who have used Go-ride and Grab-ride services at least 10 times in the last 3 months. This study uses descriptive quantitative regression data because it aims to determine the effect of two research variables, namely the independent variable on the dependent variable by using the sample testing formula. The sampling technique included in the non probability sampling technique in this study used accidental sampling.

The analysis technique in this study uses descriptive analysis techniques and hypothesis testing (multiple linear regression analysis) and data feasibility testing in the form of validity, reliability and classical assumptions. Descriptive analysis aims to describe or explain the description under study based on data from the variables obtained, and is not intended for hypothesis testing. Qualitative descriptive analysis aims to describe all research variables (Service Quality, Promotion and Customer Satisfaction). The presentation of the results of descriptive analysis is usually in the form of frequencies and percentages, cross tabulations, various forms of graphs and diagrams on categorical data, and in the form of group statistics such as mean values (Azwar, 2012). Simple linear regression analysis is used to measure the independent variable on the dependent variable, namely service quality on customer satisfaction and promotion on customer satisfaction. Data analysis using multiple regression methods was carried out by researchers using the SPSS program.

$\mathrm{X} 1$ and $\mathrm{X} 2$ as independent variables, $\mathrm{Y}$ as dependent variables. The relationship equation model in the moderated regression analysis is as follows: 
1. Goride customer satisfaction, that is:

$$
Y_{1}=a_{0}+a_{1} X_{11}+a_{2} X_{12}+e_{1}
$$

Where:

$Y_{1}$ : The dependent variable is Go-ride customer satisfaction;

$\mathrm{a}_{0}$ : constant;

$a_{1}$ : regression coefficient of Go-ride service quality variable;

$\mathrm{X}_{11}$ : quality of Go-ride service;

$\mathrm{a}_{2}$ : Go-ride promotion variable regression coefficient;

$\mathrm{X}_{12}$ : Go-ride promotions;

$\mathrm{e}_{1}$ : error term.

2. Grab-ride customer satisfaction:

$$
Y_{2}=b_{0}+b_{1} X_{21}+b_{2} X_{22}+e_{2}
$$

Where:

$\mathrm{Y}_{2}$ : The dependent variable is Grab-ride customer satisfaction;

$\mathrm{b}_{0}$ : constant;

$\mathrm{b}_{1}$ : regression coefficient of Grab-ride service quality variable;

$\mathrm{X}_{21}$ : quality of Grab-ride services;

$b_{2}$ : The regression coefficient for the Grab-ride promotion variable;

$\mathrm{X}_{22}$ : Grab-ride promo;

$\mathrm{e}_{2}$ : error term.

\section{RESULTS AND DISCUSSION}

Validity shows the extent to which measuring instruments are used to measure what is being measured. The method is to correlate the scores obtained on each question item with the individual's total score.

Validity testing was carried out with the help of a computer using the SPSS for Windows Version 22.0 program. Based on the results of the calculation of the validity test of the Gojek customer satisfaction variable with 8 question items, they are as follows:

Table 2 - Results of the Validity Test for Gojek Customer Satisfaction Variables $\left(\mathrm{Y}_{1}\right)$

\begin{tabular}{cccc}
\hline No & Total Correlation $/ \mathrm{r}_{\text {hitung }}$ Corrected Item Value & $\mathrm{r}_{\text {table }}$ & Criteria \\
\hline \hline 1 & 0,832 & 0,1966 & Valid \\
2 & 0,893 & 0,1966 & Valid \\
3 & 0,790 & 0,1966 & Valid \\
4 & 0,848 & 0,1966 & Valid \\
5 & 0,910 & 0,1966 & Valid \\
7 & 0,849 & 0,1966 & Valid \\
8 & 0,800 & 0,1966 & Valid \\
\hline
\end{tabular}

Source: Processed Data, 2020.

Based on Table 2, it can be seen that all questions for the variable customer satisfaction method have a valid status, because the value of rcount (Corrected Item-Total Correlation) $>r$ table is 0.1966 . Based on the results of the calculation of the validity test of the service quality variable with 12 question items.

Based on Table 3, it can be seen that all questions for service quality variables that have 12 questions, have a valid status, because the value of rcount (Corrected Item-Total Correlation) $>$ rtabel is 0.1966 .

Based on the results of the calculation of the validity test of the promotional variables with 9 question items, they are as follows in Table 4. 
Table 3 - Results of the Validity Test of Service Quality Variables $\left(X_{11}\right)$

\begin{tabular}{|c|c|c|c|}
\hline \multirow{2}{*}{ No } & \multicolumn{2}{|c|}{ Corrected Item Value } & \multirow[b]{2}{*}{ Criteria } \\
\hline & Total Correlation / $r_{\text {hitung }}$ & $r_{\text {table }}$ & \\
\hline 1 & 0,702 & 0,1966 & Valid \\
\hline 2 & 0,697 & 0,1966 & Valid \\
\hline 3 & 0,668 & 0,1966 & Valid \\
\hline 4 & 0,638 & 0,1966 & Valid \\
\hline 5 & 0,797 & 0,1966 & Valid \\
\hline 6 & 0,808 & 0,1966 & Valid \\
\hline 7 & 0,628 & 0,1966 & Valid \\
\hline 8 & 0,679 & 0,1966 & Valid \\
\hline 9 & 0,785 & 0,1966 & Valid \\
\hline 10 & $0,, 852$ & 0,1966 & Valid \\
\hline 11 & 0,583 & 0,1966 & Valid \\
\hline 12 & 0,798 & 0,1966 & Valid \\
\hline
\end{tabular}

Source: Processed Data, 2020.

Table 4 - Results of the Validity Test of Promotion Variables $\left(\mathrm{X}_{12}\right)$

\begin{tabular}{cccc}
\hline No & Total Correlation / hitung & rtable & Criteria \\
\hline 1 & 0,600 & 0,1966 & Valid \\
2 & 0,547 & 0,1966 & Valid \\
3 & 0,541 & 0,1966 & Valid \\
4 & 0,530 & 0,1966 & Valid \\
5 & 0,685 & 0,1966 & Valid \\
6 & 0,763 & 0,1966 & Valid \\
7 & 0,683 & 0,1966 & Valid \\
8 & 0,650 & 0,1966 & Valid \\
9 & 0,790 & 0,1966 & Valid \\
\hline
\end{tabular}

Source: Processed Data, 2020.

Based on Table 4, it can be seen that all questions for the promotional variable are valid with rcount (Corrected Item-Total Correlation)> rtabel of 0.1966 or in other words, the value of rcount for the promotional variable is greater than $r$ table.

The reliability test was carried out on the question items which were declared valid. A variable is said to be reliable or reliable if the answers to the questions are always consistent. The instrument reliability coefficient is intended to see the consistency of the answers to the statement items given by the respondent. The analysis tool uses the split half method by correlating the total odd vs even scores, then the reliability is calculated using the "Alpha Cronbach" formula. The calculation is carried out with the help of the SPSS program computer. The reliability for each of the result variables is presented in the following table:

Table 5 - Reliability Test Results

\begin{tabular}{lllll}
\hline No & Variable & Ralpha & r-critical & Criteria \\
\hline 1 & Go-ride Customer Satisfaction $\left(\mathrm{Y}_{1}\right)$ & 0,956 & 0,60 & Reliable \\
2 & Quality of Service $\left(\mathrm{X}_{11}\right)$ & 0,937 & 0,60 & Reliable \\
3 & Promotion $\left(\mathrm{X}_{12}\right)$ & 0,890 & 0,60 & Reliable \\
\hline
\end{tabular}

Source: Processed Data, 2020.

Based on Table 5, the reliability test was carried out on the question items which were declared valid. A variable is said to be reliable or reliable if the answers to the questions are always consistent. So the results of the reliability coefficient of the Go-ride customer satisfaction instrument are 0.956 , the service quality instrument is 0.937 , and the promotional instrument is 0.890 , it turns out to have a value of "Alpha Cronbach" greater than 0.60 , which means that the three instruments are declared reliable or meet the requirements.

Grab Data Instrument Test. Validity shows the extent to which measuring instruments are used to measure what is being measured. The method is to correlate the scores obtained on each question item with the individual's total score.

Validity testing was carried out with the help of a computer using the SPSS for 
Windows Version 22.0 program. In this study, the validity test was carried out on 100 respondents. Decision making is based on the value of rcount (Corrected Item-Total Correlation) $>$ rtabel of 0.1966 , for $\mathrm{df}=100-2=98$; then the item / question is valid and vice versa.

Based on the results of the calculation of the validity test of Grab customer satisfaction variable with 8 question items are as follows:

Table 6 - Results of the Grab Customer Satisfaction Variable Validity Test $\left(\mathrm{Y}_{2}\right)$

\begin{tabular}{cccc}
\hline No & Corrected Item Value & rtable & Criteria \\
\hline 1 & Total Correlation / $r_{\text {hitung }}$ & 0,1966 & 0,1966 \\
2 & 0,423 & 0,1966 & Valid \\
3 & 0,521 & 0,1966 & Valid \\
4 & 0,689 & 0,1966 & Valid \\
5 & 0,833 & 0,1966 & Valid \\
6 & 0,796 & 0,1966 & Valid \\
7 & 0,748 & 0,1966 & Valid \\
\hline
\end{tabular}

Source: Processed Data, 2020.

Based on Table 6, it can be seen that all questions for the variable customer satisfaction method have a valid status, because the value of rcount (Corrected Item-Total Correlation) $>r$ table is 0.1966 . Based on the results of the calculation of the validity test of the service quality variable with 12 question items, it is as follows.

Table 7 - Test Results of the Validity of Service Quality Variables $\left(\mathrm{X}_{21}\right)$

\begin{tabular}{cccc}
\hline No & Total Correlation $/ r_{\text {hitung }}$ Corrected Item Value & $r_{\text {table }}$ & Criteria \\
\hline \hline 1 & 0,429 & 0,1966 & Valid \\
2 & 0,440 & 0,1966 & Valid \\
3 & 0,506 & 0,1966 & Valid \\
4 & 0,745 & 0,1966 & Valid \\
5 & 0,729 & 0,1966 & Valid \\
6 & 0,772 & 0,1966 & Valid \\
8 & 0,700 & 0,1966 & Valid \\
9 & 0,589 & 0,1966 & Valid \\
10 & 0,245 & 0,1966 & Valid \\
11 & 0,226 & 0,1966 & Valid \\
\hline
\end{tabular}

Source: Processed Data, 2020.

Based on Table 7, it can be seen that all questions for service quality variables that have 12 questions, have a valid status, because the value of rcount (Corrected Item-Total Correlation) $>r$ table is 0.1966 .

Based on the results of the calculation of the validity test of the promotion variable with 9 question items, it is as follows.

Table 8 - Results of the Validity Test of Promotion Variables $\left(\mathrm{X}_{22}\right)$

\begin{tabular}{|c|c|c|c|}
\hline \multirow{2}{*}{ No } & \multicolumn{2}{|c|}{ Corrected Item Value } & \multirow[b]{2}{*}{ Criteria } \\
\hline & Total Correlation / $r_{\text {hitung }}$ & rtable & \\
\hline 1 & 0,600 & 0,1966 & Valid \\
\hline 2 & 0,547 & 0,1966 & Valid \\
\hline 3 & 0,541 & 0,1966 & Valid \\
\hline 4 & 0,530 & 0,1966 & Valid \\
\hline 5 & 0,685 & 0,1966 & Valid \\
\hline 6 & 0,763 & 0,1966 & Valid \\
\hline 7 & 0,683 & 0,1966 & Valid \\
\hline 8 & 0,650 & 0,1966 & Valid \\
\hline 9 & 0,790 & 0,1966 & Valid \\
\hline
\end{tabular}

Source: Processed Data, 2020. 
Based on Table 8, it can be seen that all questions for the promotional variable are valid with rcount (Corrected Item-Total Correlation)> rtabel of 0.1966 or in other words, the value of rcount for the promotional variable is greater than $r$ table.

The reliability test was carried out on the question items which were declared valid. A variable is said to be reliable or reliable if the answers to the questions are always consistent. The instrument reliability coefficient is intended to see the consistency of the answers to the statement items given by the respondent. The analysis tool uses the split half method by correlating the total odd vs even scores, then the reliability is calculated using the "Alpha Cronbach" formula. The calculation is carried out with the help of the SPSS program computer. The reliability for each of the result variables is presented in the following table:

Table 9 - Reliability Test Results

\begin{tabular}{lllll}
\hline No & Variabel & Ralpha & r-critical & Criteria \\
\hline 1 & Grab Customer Satisfaction $\left(\mathrm{Y}_{2}\right)$ & 0,878 & 0,60 & Reliabel \\
2 & Quality of Service $\left(\mathrm{X}_{21}\right)$ & 0,864 & 0,60 & Reliabel \\
3 & Promotion $\left(\mathrm{X}_{22}\right)$ & 0,890 & 0,60 & Reliabel \\
\hline
\end{tabular}

Source: Processed Data, 2020.

Based on Table 9, the reliability test was carried out on the question items that were declared valid. A variable is said to be reliable or reliable if the answers to the questions are always consistent. So the reliability coefficient of the Grab customer satisfaction instrument is 0.878 , the service quality instrument is 0.864 , and the promotional instrument is 0.890 , it turns out that the Cronbach Alpha value is greater than 0.60 , which means that the three instruments are declared reliable or meet the requirements.

\section{DISCUSSION OF RESULTS}

Go-Ride and Grab Ride Classic Assumption Test Results. This classical assumption test aims to test the feasibility of the multiple regression model used in this study. This test is also intended to ensure that the regression model used is absent, multicollinearity and heteroscedasticity. The results of the assumption test are as follows:

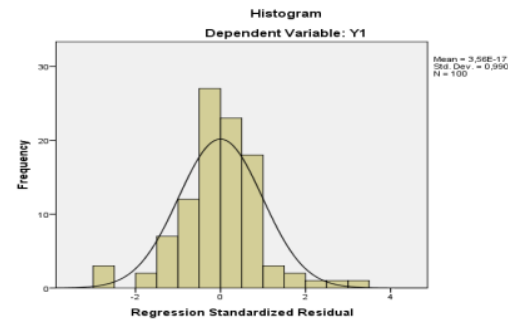

Figure 5 Normality Test

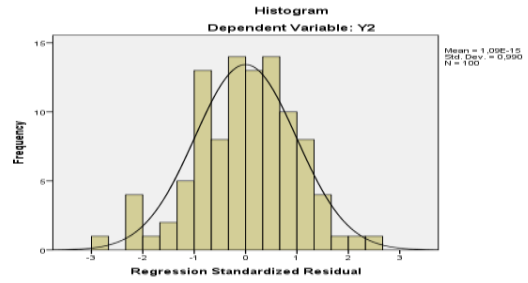

Figure 7 Normality Test

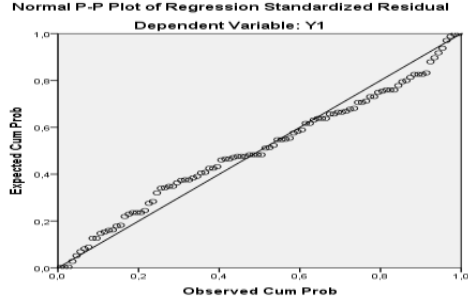

Figure 6 Normality Testing -Scatterplot

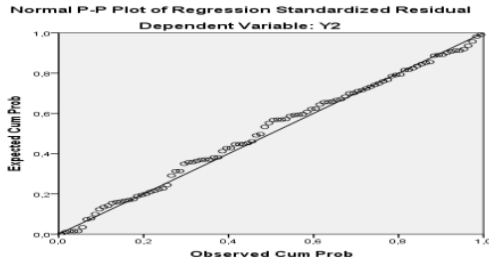

Figure 8 Normality Testing -Scatterplot

From Figure 5 above shows the bar histogram from the Go-Ride normality test results, it can be seen that the data distribution is distributed according to the distribution of the normal curve. Thus, it can be said that the data in this study were normally distributed. This result is supported by the results of the scatterplot in Figure 6, which shows that the data 
used in the study has spread out on a diagonal axis. If the points move away or spread and do not follow the diagonal line, this indicates that the residual value is not normally distributed. Based on these results, the points resulting from the analysis still follow the diagonal line, so the data is normally distributed.

From Figure 7 above, the bar histogram from the Grab-Ride normality test shows that the data distribution is distributed according to the distribution of the normal curve. Thus it can be said that the data in this study were normally distributed. This result is supported by the results of the scatterplot in Figure 8, which shows that the data used in the study has spread on the diagonal axis. If the points move away or spread and do not follow the diagonal line, this indicates that the residual value is not normally distributed. Based on these results, the points resulting from the analysis still follow the diagonal line, so the data is normally distributed.

The multicollinearity test aims to test whether the regression model found a high correlation between the independent variables. If there is a high correlation, then there is a multicolinearity problem. A good regression model should not have a high correlation between the independent variables.

Testing the presence or absence of multicollinearity symptoms is done by looking at the VIF (Variance Inflation Factor) and Tolerance values. If the VIF value is below 10, then the regression value does not have a multicollinearity problem. The multicollinearity test results of the marketing performance equation model are presented in table 10 below:

Table 10 Multicollinearity Test on Go-Ride Customer Satisfaction Model Regression

\begin{tabular}{|c|c|c|c|}
\hline \multicolumn{4}{|c|}{ Coefficients $^{a}$} \\
\hline \multirow{2}{*}{\multicolumn{2}{|c|}{ Model }} & \multicolumn{2}{|c|}{ Collinearity Statistics } \\
\hline & & Tolerance & VIF \\
\hline 1 & $\begin{array}{l}\text { (Constant) } \\
\text { Quality of Service }\left(X_{11}\right) \\
\text { Promotion }\left(X_{12}\right)\end{array}$ & $\begin{array}{l}682 \\
682\end{array}$ & $\begin{array}{l}1,467 \\
1,467\end{array}$ \\
\hline
\end{tabular}

a. Dependent Variable: Go-ride Customer Satisfaction $\left(Y_{1}\right)$.

Source: Processed Data, 2020.

Based on Table 10, it can be seen that the VIF value for the service quality variable for Go-Ride produces a value of 1.467 , and the promotional variable is 1.467 . The results of the multicollinearity test with the VIF value of each variable showed a value less than 10.00 . For the results of the tolerance value for the service quality variable, the value is 0.682 , and the promotion variable is 0.682 . The tolerance value for each variable shows a value of more than 0.10 , so it can be concluded that there is no multicollinearity relationship in the Go-ride customer satisfaction regression equation model.

Table 11 - Multicollinearity Test on the Grab Ride Customer Satisfaction Model Regression

\begin{tabular}{llll}
\hline Coefficients $^{\mathrm{a}}$ & & \\
\hline \multirow{2}{*}{ Model } & & Collinearity Statistics & \\
\cline { 3 - 4 } & (Constant) & & Tolerance \\
\hline \multirow{2}{*}{1} & Quality of Service $\left(\mathrm{X}_{21}\right)$ & 1,000 & 1,000 \\
& Promotion $\left(\mathrm{X}_{22}\right)$ & 1,000 & 1,000 \\
\hline
\end{tabular}

a. Dependent Variable: Grab Customer Satisfaction $\left(Y_{2}\right)$.

Source: Processed Data, 2020.

Based on Table 11, it can be seen that the VIF value for the service quality variable for Grab Ride produces a value of 1,000 , and the promotional variable is 1,000 . The results of the multicollinearity test with the VIF value of each variable showed a value less than 10.00 . For the results of the tolerance value for the service quality variable, the value is 1,000 , and the promotion variable is 1,000 . The tolerance value for each variable shows a value of more than 0.10 , so it can be concluded that there is no multicollinearity relationship in the Go-ride customer satisfaction regression equation model. 
Heteroscedasticity test to detect the presence or absence of heteroscedasticity is by looking at the plot graph between the predicted value of the dependent variable, namely ZPRED and the residual SRESID. If there is a certain pattern such as dots that form a certain regular pattern, heteroscedasticity has occurred. Conversely, if it does not form a certain regular pattern, heteroscedasticity will not occur.

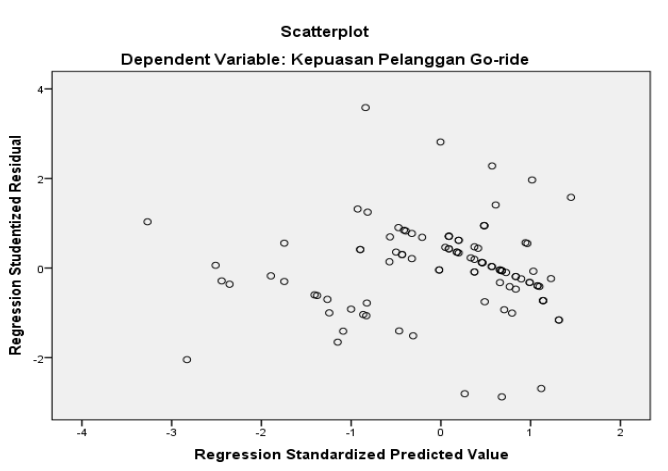

Figure 9 - Go-Ride Heteroscedasticity Test

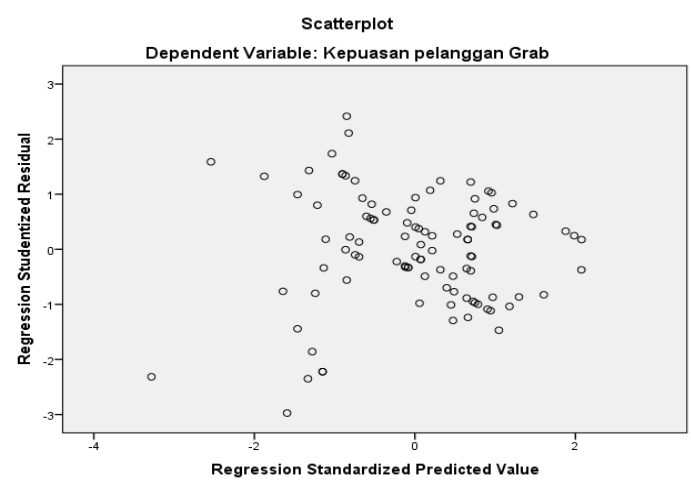

Figure 10 - Grab Ride Heteroscedasticity Test

Based on the picture above, it can be concluded that the results of data analysis for the three variables, both go ride and grab ride, do not form a certain regular pattern, so it can be said that heteroscedasticity does not occur.

The results of the regression equation for the variable marketing performance, special capabilities and customer demands of Go-Ride can be shown in table 12:

Table 12 - Go-Ride Multiple Linear Regression Results

\begin{tabular}{|c|c|c|c|c|c|}
\hline \multicolumn{6}{|l|}{ Coefficients $^{a}$} \\
\hline \multirow[b]{2}{*}{ Model } & Unstd & ed Coefficients & Stdanardized Coefficients & \multirow{2}{*}{$\mathrm{T}$} & \multirow{2}{*}{ Sig. } \\
\hline & B & Std. Error & Beta & & \\
\hline \multirow{3}{*}{$\begin{array}{ll}1 & \text { (Constant) } \\
& \text { Quality of Service }\left(X_{11}\right) \\
& \text { Promotion }\left(X_{12}\right)\end{array}$} & 9,245 & 2,581 & & 3,583 & ,001 \\
\hline & ,260 &, 066 & ,375 & 3,965 &, 000 \\
\hline & ,320 & ,087 & ,349 & 3,699 &, 000 \\
\hline
\end{tabular}

a. Dependent Variable: Go-ride Customer Satisfaction $\left(Y_{1}\right)$.

Source: Processed Data, 2020.

Based on the results of statistical calculations as in table 12, the multiple linear regression equation is obtained on the following consumptive behavior:

$$
Y_{1}=9.245+0,260 X_{11}+0,320 X_{12}+\text { ei }
$$

Where:

$\mathrm{X}_{11}$ : Quality of Service;

$\mathrm{X}_{12}$ : Promotion;

$Y_{1}$ : Go-ride Customer Satisfaction.

The estimation results show that the coefficient value for the Service Quality variable (X11) is 0.260 and has a positive relationship, which means that when the service quality variable increases, the Go-ride customer satisfaction variable will also increase by 0.260 with a probability value of $0.000<0,05$, the degree of error is $5 \%$, so it is statistically significant and has an effect on Go-ride customer satisfaction.

The coefficient value for the Promotion variable (X12) is 0.320 and has a positive relationship, which means that when the need for promotion increases, the Go-ride customer satisfaction variable will also increase by 0.320 with a probability value of $0.000<0.05$ degrees of error of $5 \%$ so it is statistically significant and affects Go-ride customer satisfaction. 
Table 13 - Multiple Linear Regression Results for Grab Ride

\begin{tabular}{|c|c|c|c|c|c|}
\hline \multicolumn{6}{|l|}{ Coefficients $^{\mathrm{a}}$} \\
\hline \multirow[b]{2}{*}{ Model } & \multicolumn{2}{|c|}{ Unstdanardized Coefficients } & Stdanardized Coefficients & \multirow{2}{*}{$\mathrm{T}$} & \multirow{2}{*}{ Sig. } \\
\hline & $B$ & Std. Error & Beta & & \\
\hline 1 (Constant) & 21,161 & 3,285 & & 6,442 & 000 \\
\hline Quality of Service $\left(X_{21}\right)$ & ,369 &, 050 &, 592 & 7,335 & ,000 \\
\hline Promotion $\left(\mathrm{X}_{22}\right)$ &,- 111 & .075 &,- 120 & $-1,481$ & 142 \\
\hline
\end{tabular}

a. Dependent Variable: Grab Customer Satisfaction $\left(Y_{2}\right)$.

Source: Processed Data, 2020.

Based on the results of statistical calculations as in table 13, the multiple linear regression equation is obtained on Grab Customer Satisfaction as follows:

$$
Y_{1}=21.161+0,369 X_{21}-0,111 X_{22}+e i
$$

Where:

$\mathrm{X}_{21}$ : Quality of Service;

$\mathrm{X}_{22}$ : Promotion;

$\mathrm{Y}_{2}$ : Grab Customer Satisfaction.

The estimation results show that the coefficient value for the Service Quality variable (X21) is 0.369 and has a positive relationship, which means that when the service quality variable increases, the Grab customer satisfaction variable will also increase by 0.369 with a probability value of $0.000<0.05$ degrees. error of $5 \%$ so it is statistically significant and affects Grab customer satisfaction.

The coefficient value for the Promotion variable (X22) is 0.111 and has a negative relationship, which means that when the need for promotion increases, the Go-ride customer satisfaction variable will not increase by 0.111 with a probability value of $0.142>0.05$ degrees of error of $5 \%$ so that it is statistically insignificant and has no effect on Grab customer satisfaction.

The $\mathrm{F}$ test is performed to see the effect of the independent variables on the dependent variable collectively or as a whole. The parameter is if the F-count value is greater than the F-table value or the F-count probability value is smaller than the alpha $(\alpha)$ value, it can be said that overall the independent variables in the model have a significant effect on the dependent variable. The following is a table of the results of the F Test below:

Table 14 - Go-Ride F Test Results

\begin{tabular}{llllll} 
ANOVA $^{\mathrm{a}}$ & & & & & \\
\hline Model & Sum of Squares & Df & Mean Square & F & Sig. \\
\hline 1 Regression & 864,583 & 2 & 432,291 & 33,707 &, $000^{\mathrm{b}}$ \\
Residual & 1244,007 & 97 & 12,825 & & \\
Total & 2108,590 & 99 & & & \\
\hline
\end{tabular}

\footnotetext{
a. Dependent Variable: $Y 1$.

b. Predictors: (Constant), X12, X11.

Source: Processed Data, 2020.
}

Based on Table 14, it is obtained that the Fcount value is 33,707 and a significance value of 0,000 then Ftable is calculated with df 1 (the number of free variables is 2) and df 2 (the number of samples is 100-2-1) with a significance level of 0.05 , the value is 3.09 . Illustrates that Fcount> Ftable with a significance value below 0.05 . Thus, $\mathrm{HO}$ is rejected, which means that the variable quality of service and promotion has a significant effect on Goride customer satisfaction.

Based on Table 15, it is obtained that the Fcount value is 28,223 and a significance value is 0,000 then Ftable is calculated with df 1 (the number of free variables is 2) and df 2 (the number of samples is 100-2-1) with a significance level of 0.05 then the value is obtained 3.09. Illustrates that Fcount> Ftable with a significance value below 0.05 . Thus, H0 is rejected, which means that the variable service quality and promotion has a significant effect on Grab Ride customer satisfaction. 
Table 15 - Grab Ride F Test Results

ANOVA $^{a}$

\begin{tabular}{llllll}
\hline Model & Sum of Squares & Df & Mean Square & $F$ & Sig. \\
\hline 1 Regression & 797,120 & 2 & 398,560 & 28,223 &, $000^{\mathrm{b}}$ \\
Residual & 1369,840 & 97 & 14,122 & & \\
Total & 2166,960 & 99 & & & \\
\hline
\end{tabular}

a. Dependent Variable: Y2.

b. Predictors: (Constant), X22, X21.

Source: Processed Data, 2020.

The $t$ test is used to determine whether the independent variable partially affects the dependent variable or not. The t test results are shown in table 16:

Table 16 - Go-Ride t Test Results

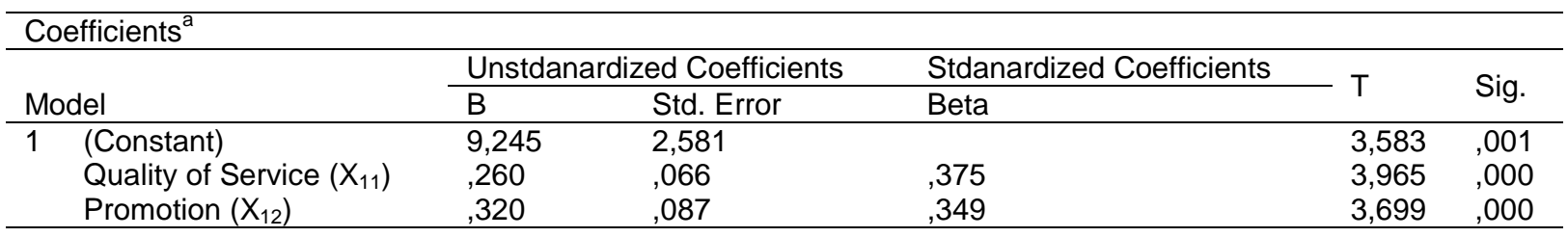

a. Dependent Variable: Go-ride Customer Satisfaction $\left(Y_{1}\right)$.

Source: Processed Data, 2020.

Table 16 shows that the $t$ count of the service quality variable on Go-ride customer satisfaction is 3,965 with a t-table value of 1.660 , the significance of 0.000 is less than 0.05 . Based on the decision criteria tcount> ttable $(3,965>1,660)$, it means that $\mathrm{HO}$ is rejected, which means that service quality has a significant effect on Go-ride customer satisfaction. Meanwhile, the promotion variable on Go-ride customer satisfaction is 3,699 with a t-table value of 1,660 , the significance of 0,000 is less than 0.05 . Based on the decision criteria tcount $>$ ttable $(3,965>1,660)$, it means that $\mathrm{HO}$ is rejected, which means that promotion has a significant effect on Go-ride customer satisfaction.

Table 17 - Grab ride t-test results

\begin{tabular}{|c|c|c|c|c|c|}
\hline \multicolumn{6}{|l|}{ Coefficients $^{\mathrm{a}}$} \\
\hline \multirow[b]{2}{*}{ Model } & Unstda & d Coefficients & Stdanardized Coefficients & \multirow{2}{*}{$\mathrm{T}$} & \multirow{2}{*}{ Sig. } \\
\hline & $\mathrm{B}$ & Std. Error & Beta & & \\
\hline \multirow{3}{*}{ 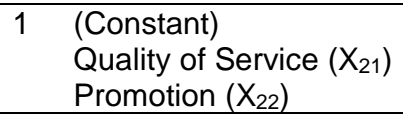 } & 21,161 & 3,285 & & 6,442 & ,000 \\
\hline & ,369 & ,050 &, 592 & 7,335 &, 000 \\
\hline & ,111 & ,075 &, 120 & 1,881 &, 000 \\
\hline
\end{tabular}

a. Dependent Variable: Grab Customer Satisfaction $\left(Y_{2}\right)$.

Source: Processed Data, 2020.

Table 17 shows that the tcount of service quality variables on Grab ride customer satisfaction is 7,335 with a t-table value of 1.660 , the significance of 0.000 is less than 0.05 . Based on the decision criteria tcount> ttable $(7,335>1,660)$, it means that $\mathrm{HO}$ is rejected, which means that service quality has a significant effect on Grab customer satisfaction. As for the promotion variable on Grab customer satisfaction of 1.881 with a t-table value of 1.660 , the significance of 0.000 is less than 0.05 . Based on the decision criteria tcount> ttable $(1.881>1.660)$, it means that $\mathrm{HO}$ is rejected, which means that promotion has a significant effect on Grab customer satisfaction. The value of the coefficient of determination (R-squared) illustrates the ability of the regression model to explain variations in the dependent variable, while values outside the coefficient of determination (1- R2) are explained by other factors outside the research analysis model. The following table below is the test results of the Determination Coefficient R2:

The R-square value in the regression equation is 0.410 or 41 percent, meaning that the variation of the independent variables used in the service quality and promotion model is 
able to explain 41 percent of the variation of Go-ride customer satisfaction variables, while the remaining 59 percent is explained by other variables that are not included in this research model.

Table 18 Results of Testing the Coefficient of Determination of the Go-Ride Marketing Performance Model

Model Summary

\begin{tabular}{lllll}
\hline Model & $\mathrm{R}$ & $\mathrm{R}$ Square & Adjusted R Square & Std. Error of the Estimate \\
\hline 1 &, $640^{\mathrm{a}}$ &, 410 &, 398 & 3,581 \\
\hline
\end{tabular}

a. Predictors: (Constant), X12, X11.

Source: Processed Data, 2020.

Table 19 - Results of Testing the Coefficient of Determination of the Grab Ride Marketing Performance Model

Model Summary

\begin{tabular}{lllll}
\hline Model & $\mathrm{R}$ & $\mathrm{R}$ Square & Adjusted R Square & Std. Error of the Estimate \\
\hline 1 &, $607^{\mathrm{a}}$ &, 368 &, 355 & 3,758 \\
\hline
\end{tabular}

a. Predictors: (Constant), X22, X21.

Source: Processed Data, 2020.

The R-square value in the regression equation is 0.368 or 36 percent, meaning that the variation of the independent variables used in the service quality and promotion model is able to explain 36 percent of the variation in the Grab customer satisfaction variable, while the remaining 64 percent is explained by other variables not included in the this research model.

\section{CONCLUSION}

Based on the analysis and discussion of the Comparative Study of Service Quality and Promotion on Customer Satisfaction of Go-Ride and Grab-Ride Online Transportation Services in Palembang City, the following conclusions can be drawn:

1. The quality of Go-ride and Grab-Ride services has a significant effect on Customer Satisfaction of Online Transportation Services in Palembang City. This is evidenced by the t value of 3.965 with a significance value of 0.000 less than $0.05(0.000<0.05)$, and the variable regression coefficient of Go-ride service quality of 0.260 . Meanwhile, the $t$ value of Grab-ride is 7.335, with a significance value of 0.000 , less than 0.05 $(0.000<0.05)$, and the regression coefficient of the Grab-ride service quality variable is 0.369 ;

2. Go-ride and Grab-Ride promotions have a significant effect on Customer Satisfaction of Online Transportation Services in Palembang City. This is evidenced by the t value of 3.699 with a significance value of 0.000 less than $0.05(0.000<0.05)$, and the regression coefficient of the Go-ride promotion variable of 0.320 . While the t value of Grab-ride is 1.881, with a significance value of 0.000 , less than $0.05(0.000<0.05)$, and the regression coefficient of the Grab-ride promotion variable is 0.111 .

Although this research has been attempted optimally, there are still limitations to this research. Limitations in this study include the number of variables involved is still very limited, namely service quality, promotion and customer satisfaction. The data collection method uses a questionnaire, so it is very possible that the data is subjective, it would be better to add an interview method to go-rides and grab rides as well as customers so that the research results obtained are more complete.

Based on the research results, discussion and conclusions obtained, the following suggestions can be given.

1. For the Company:

- Customer satisfaction in using go-ride and grab ride services is reasonable because of the incessant promotions that have been carried out and supported by 
the good quality of service provided. Online transportation companies should pay more attention to the quality of services provided to consumers, both in terms of price and in terms of technology. Thus the goal of online transportation to increase income can be achieved.

- Sustainability in promotion is needed to remind consumers that this online transportation has an advantage and convenience for the users of this transportation.

2. For Further Researchers:

For future researchers who want to research or continue this research, it is advisable to continue or develop this research by looking for other factors such as advertisements, discounts, etc. that can affect customer satisfaction in using online transportation, both Goride and Grab-ride in the City. Palembang.

\section{REFERENCES}

1. Bugin, Burhan. (2004). Quantitative Research Methodology. Jakarta: Kencana Prenada Media Group.

2. Buttle, Francis. (2007). Customer Relationship Management. Jakarta: Bayumedia.

3. Engel, James F and Blackwell, Roger D and Miniard, Paul W. (1995). Consumer behavior. Jakarta: Binarupa Literacy.

4. Ghozali, Imam and John Castellan. (2002). Non-Parametric Statistics: Theory and Application with the SPSS Program. Semarang: Diponegoro University Publishing Agency.

5. Ghozali, Imam. (2006). Multivariate Analysis Application with SPSS Program (4th ed.). Semarang. Publishing Agency of Diponegoro University Semarang.

6. Joon Choi, B., \& Sik Kim, H. (2013). The impact of outcome quality, interaction quality, and peer-to-peer quality on customer satisfaction with a hospital service. Managing Service Quality: An International Journal, 23 (3).

7. Kertajaya, H. (2004). On Marketing. Jakarta: PT Gramedia Pustaka Utama.

8. Kotler, Philip and Armstrong, Gary. (2012). Marketing Principles Volume 14 Edition 1. Jakarta: Erlangga.

9. Kotler, Philip and Keller, Kevin. (2016). 13th Edition Marketing Management Jakarta: Erlangga.

10. Lupiyoadi, Rahmat. (2001). Service Marketing Management. Jakarta: Four Salemba.

11. Lupioyadi, Rambat, and Hamdani, A. (2009). Marketing Management Services. Jakrta: Salemba Empat.

12. Lupiyodi, Rambat (2013). Competency-Based Service Marketing Management, third edition. Jakarta: Four Salemba.

13. Malhotra, Naresh K (2010). Marketing Research: An Applied Orientation. (6th ed). New Jersey: Pearson Education.

14. Mardikawati, Woro and Farida, Naili (2013). The Influence of Customer Value and Service Quality on Customer Loyalty through Customer Satisfaction on Bus Customer Efficiency. Journal of Business Administration, Semarang: Diponegoro University.

15. Mowen, John C and Minor, Micheal. (2012). Dwi Kartika Yahya's translation of consumer behavior. Jakarta: Erlangga.

16. Parasuraman, A., (2014). The Behaviorial Consequenses of Service Quality. New Jersey: Prince Hall.

17. Rajagopal. (2012), Marketing Dynamics (theory and practice), New Age International Pvt Ltd Publishers; 1st Ed Edition.

18. Rehman, A. Abdul. (2012). Customer satisfaction and service quality in Islamic banking. Qualitative Research in Financial Markets, 4 (2/3).

19. Santoso, Singgih (2015). Non Parametric Statistics SPSS Exercise. Jakarta: PT ElexMedia Komputindo.

20. Sarwono, Jonathan (2006). Quantitative and Qualitative Research Methods. Yogyakarta: Graha Science. 
21. Setiyanto, Danu Aris (2016). A Social Note about Science, Islam, and Indonesia. Yogjakarta: Deep publish.

22. Sheng, T., \& Liu, C. (2010). An empirical study on the effect of e-service quality on online customer satisfaction and loyalty. Nankai Business Review International, 1 (3).

23. Simamora, B (2013). Winning Markets with Effective and Reliable Marketing. Jakarta: Gramedia Pustaka Utama.

24. Sugiyono (2012). Business Research Methods. Bandung: CV Alfabeta.

25. Sundayana, Rostina. (2014). Educational Research Statistics. Bandung: CV Alfabeta.

26. Surachman, S.A. (2008). Brand Management Basics. Malang: Bayumedia Publishing.

27. Sutisna. (2015). Consumer behavior. Bandung: Rosda Karya.

28. Tjiptono, Fandy (2014). Service Marketing, Principles, Application, and Research. Yogyakarta: Andi.

29. Tjiptono, Fandy et al (2016). Marketing Services. Malang: Bayumedia.

30. Yuliarmi, Ni Nyoman and Riyasa, Putu (2014). Analysis of Factors Affecting Customer Satisfaction of PDAM Denpasar City Services. Economic Studies Bulletin. Vol 12 No.1.

31. Electronic Source: www.go-jek.com.

32. Electronic Source: www.top-brandaward.com.

33. Electronic Source: www.databoks.katadata.co.id.

34. Electronic Source: www.ylki.co.id. 